\title{
Topical treatment of ointment containing ethanol extract of Archidendron pauciflorum fruit peel on the wound healing in streptozotocin-induced diabetic mice
}

\author{
DESAK MADE MALINI ${ }^{1, \vartheta}$, MADIHAH ${ }^{1}$, FITRI KAMILAWATI ${ }^{1}$, NINING RATNINGSIH ${ }^{1}$, \\ KARTIAWATI ALIPIN ${ }^{1}$, JOHAN ISKANDAR ${ }^{1}$ \\ ${ }^{1}$ Department of Biology, Faculty of Mathematics and Natural Sciences, Universitas Padjadjaran. Jl. Raya Bandung-Sumedang Km. 21 Jatinangor, \\ Sumedang 45363, West Java, Indonesia. Tel./Fax. +62-22-7796412, `email: desak.made@unpad.ac.id
}

Manuscript received: 15 July 2017. Revision accepted: 25 August 2017.

\begin{abstract}
Malini DM, Madihah, Kamilawati F, Ratningsih N, Alipin K, Iskandar J. 2017. Topical treatment of ointment containing ethanol extract of Archidendron pauciflorum fruit peel on the wound healing in streptozotocin-induced diabetic mice. Nusantara Bioscience 9: 306-311. Diabetic wounds lead to severe tissue damage and are difficult to cure. One alternative medicine known well by local Indonesian communities to treat diabetic wounds is the fruit peel of djengkol. This study aimed to evaluate the ointment containing ethanol extract of djengkol fruit peel to accelerate wound healing process in the skin of streptozotocin-induced diabetic mice. The method was experimental using completely randomized design with six treatments and four replications. Diabetes was induced by intraperitoneal injection of streptozotocin $180 \mathrm{mg} / \mathrm{kg}$ BW. Mice with blood glucose level $\geq 150 \mathrm{mg} / \mathrm{dL}$ were used for diabetic mice models. The incision wound created at dorsolateral region of shaven skin at $\pm 1 \mathrm{~cm}^{2}$ using sterile scissors. The ointment containing extract was applied topically to the diabetic mice wounds at concentration of $5 \%, 10 \%$ and $15 \%$, as well as Betadine ${ }^{\circledR}$ as the reference group. The ointment basis was applied to the wound of diabetic mice as a positive control and to the wound of non-diabetic mice as a negative control. The treatment was done twice a day for 14 days. The results showed that topical application of ointment containing ethanol extract of djengkol fruit peel at concentration of $10 \%$ gave significant recovery $(\mathrm{p}<0.05)$ on the wounded skin by the enhancement of re-epithelization and granulation tissue, as well as the increase of capillary number and collagen density which were higher than other treatments and comparable to negative control group. It was concluded that the topical application of ointment containing ethanol extract of djengkol fruit peel can support the healing of diabetic wounds.
\end{abstract}

Keywords: Archidendron pauciflorum, diabetic, djengkol, skin, streptozotocin, topical application

Abbreviations: DM = Diabetes Mellitus, DFUs = Diabetic Foot Ulcers, EPC $=$ Endothelial Progenitor Cells, EEJFP = Ethanol Extract of Djengkol Fruit Peel, STZ = Streptozotocin

\section{INTRODUCTION}

Diabetes Mellitus (DM) is a chronic disease in which individuals lose the ability to regulate the level of sugar in their blood caused by the unability of pancreas to produce insulin or the body cannot use it effectively which leads to raised glucose levels in the blood (hyperglycemia). Over the long-term high glucose levels are associated with damage to the body and failure of various organs and tissues (International Diabetes Federation 2017). Many diabetic patients have difficulty in healing wounds, which in particular, wounds affecting the feet are common and called diabetic foot ulcers (DFUs). DFUs constitute one of the most common complications of this disease. About $58 \%$ of ulcers become clinically infected often leading to amputation (Mendes and Neves 2012).

Wound healing is a dynamic and complex biological process that can be divided into four partly overlapping phases: hemostasis, inflammation, proliferative and remodeling. These phases involve a large number of cell types, extracellular components, growth factors, and cytokines. Diabetes mellitus causes impaired wound healing by affecting one or more biological mechanisms of these processes (Baltzis et al. 2014). Diabetic wounds estimated to occur in $15 \%$ of diabetic patients and often cause pain and could reduce productivity. A series of multiple mechanisms, including decreased cell and growth factor response, leads to diminished peripheral blood flow and decreased local angiogenesis, all of which can contribute to the lack of healing in person with diabetic wounds (Brem and Tomic-Canic 2007).

Diabetic wounds have to be treated with the right medicine to accelerate wound healing and prevent infection in wounds, including by using herbal medicine. Herbal medicines are being used by about $80 \%$ of the population in developing countries for primary health care, including treating wounds, infectious and metabolic diseases, due to their efficacy, safety, cultural acceptability, and fewer side effects (Agyare et al. 2015). The phytomedicines for wound healing are not only cheap and affordable but are also purportedly safe as hyper sensitive reactions are rarely encountered with the use of these agents (Singh et al. 2014). One of the herbal medicines to treat wounds is djengkol (Archidendron pauciflorum (Benth.) I.C. Nielsen). In order to treat wounds, ashes of burnt young leaves are applied onto the injured area, whereas raw-eaten 
seeds are used to purify the blood and to serve as antidiabetic agent (Bunawan et al. 2013). Our previous study showed that local people in Karangwangi village, Cianjur District, West Java used the water decoction of dried djengkol fruit peels to decrease blood sugar levels. Djengkol fruit peel is known to contain saponin, glycosides, and steroids (triterpenoids) (Wahyuni et al. 2012) as well as alkaloids, flavonoids, tannin, quinones, and polyphenols (Syafnir et al. 2014; Sihombing et al. 2015).

Djengkol fruit peel has pharmacological activities as anti-hyperglycemia, antimicrobial and antioxidant due to the phytochemical contents (Bunawan et al. 2013). This study aimed to evaluate the ointment containing ethanol extract of djengkol fruit peel (EEJFP) to accelerate wound healing process in the skin of streptozotocin-induced diabetic mice. Streptozotocin (STZ; 2-deoxy-2-[3- (3methyl-nitrosourea)-D-gluco piranose]) is a permanent diabetogenic agent which are toxic molecules causing damage to pancreatic beta cells (Szkudelski 2001). Rodent models of diabetic wound healing have received a great deal of focus due to ease of maintenance, cost and availability of genetically modified lines. A full-thickness wound model is a standard approach which removed both epidermal and dermal tissues, allowing evaluation of reepithelialization, granulation, and angiogenesis, all key processes during physiological wound healing (Suckow et al. 2017). In this study, the EEJFP is in the form of an ointment, thus the active ingredient in the extract could persist longer on the surfaces and penetrate optimally into the skin (Yanhendri and Yenny 2012).

\section{MATERIALS AND METHODS}

\section{Preparations of the ointment}

Djengkol fruit peel was collected from Karangwangi village, Cianjur District, West Java Province, Indonesia. The samples were identified in Taxonomy laboratory in Biology Department, Faculty of Mathematics and Sciences, University of Padjadjaran. The samples were air-dried to a constant weight and blend to a coarse powder. The dried powder was soaked and macerated on ethanol 70\% (ratio 1:2) for 72 hours and every 24 hours the macerate was collected. The macerate was then evaporated using a rotary evaporator at a temperature of $40-50^{\circ} \mathrm{C}$, and freeze-dried to obtain a paste extract. The ointment was made by mixing petroleum jelly and ethanol extract of djengkol fruit peel at concentration of $5 \%, 10 \%$, and $15 \%(\mathrm{w} / \mathrm{w})$.

\section{Experimental design}

Twenty-four male Swiss-Webster mice (8-12 weeks old, 30-40 g of weight) were obtained from the Faculty of Animal Husbandry University of Padjadjaran. They were housed in standard environmental condition and fed with piglet standard diets (CP-551, PT. Charoen Pokphand) and water ad libitum. The animals were acclimatized for seven days before the experiment. The experiment used completely randomized design with six treatments and four replications (Table 1).

\section{Induction of diabetes}

The animals fasted for 4-6 hours, and their baseline fasting blood glucose level were measured using a glucometer, by collecting blood via tail cut before induction of diabetes. Diabetes was induced by intraperitoneal injection of a freshly prepared solution of STZ (Nacalai Tesque, Inc.) with a dose of $180 \mathrm{mg} / \mathrm{kg} \mathrm{BW}$ in $10 \mathrm{mM}$ citrate buffer solution $\mathrm{pH} 4.5$ of five groups, while the negative control rats were injected with the vehicle. The mice were provided by $10 \%$ of sucrose solution for three constitutive days to prevent hypoglycemia after STZ induction. Four days after administration of STZ, the mice fasted and the blood was collected via tail cut for measuring their fasting glucose levels. The animals which have glucose level more than $150 \mathrm{mg} / \mathrm{dL}$ were used for further experiment and categorized as diabetic mice (Wu and Huan 2008; Furman, 2015)

\section{Procedure of the wound creation and treatment with the ointment}

The mice were euthanized with inhaled ether, and then the hair on right side of cutting area was shaved before the creation of wound. Incision wounds were created on all mice by cutting the dorsolateral surface of skin $\pm 1,5 \mathrm{~cm}$ from the shaven area using sterile scissors (full-thickness type extending up to the adipose tissue). The ointment treatment was given twice a day in the morning and afternoon for 14 days. The animals were allowed to consume food and water ad libitum (Chen et al. 2005; Winarsih et al. 2012).

Table 1. Experimental design of the treatment

\begin{tabular}{|c|c|c|c|c|}
\hline \multirow[b]{2}{*}{$\mathbf{S} / \mathbf{N}$} & \multirow[b]{2}{*}{ ID } & \multicolumn{3}{|c|}{ Treatments } \\
\hline & & $\begin{array}{l}\text { Induction of diabetes by } \\
\text { STZ } 180 \mathrm{mg} / \mathrm{kg} \mathrm{BW}\end{array}$ & $\begin{array}{l}\text { Incision wound } \\
\text { creation }\end{array}$ & Treatment with the ointment \\
\hline $\mathrm{A}$ & Negative control (NC) & - & + & Petroleum jelly \\
\hline $\mathrm{B}$ & Positive control (PC) & + & + & Petroleum jelly \\
\hline $\mathrm{C}$ & Reference (REF) & + & + & Betadine $₫$ ointment \\
\hline $\mathrm{D}$ & $\begin{array}{l}\text { Ointment containing extract } \\
\text { treatment } 1 \text { (EO1) }\end{array}$ & + & + & $\begin{array}{l}\text { EEJFP ointment at concentration } \\
5 \%(\mathrm{w} / \mathrm{w})\end{array}$ \\
\hline $\mathrm{E}$ & $\begin{array}{l}\text { Ointment containing extract } \\
\text { treatment } 2(\mathrm{EO} 2)\end{array}$ & + & + & $\begin{array}{l}\text { EEJFP ointment at concentration } \\
10 \%(\mathrm{w} / \mathrm{w})\end{array}$ \\
\hline $\mathrm{F}$ & $\begin{array}{l}\text { Ointment containing extract } \\
\text { treatment } 3 \text { (EO3) }\end{array}$ & + & + & $\begin{array}{l}\text { EEJFP ointment at concentration } \\
15 \%(\mathrm{w} / \mathrm{w})\end{array}$ \\
\hline
\end{tabular}




\section{Histological preparation and examination}

On the $15^{\text {th }}$ days, after an overnight fast, the animals were weighted and sacrificed by cervical dislocation, wounds were harvested and fixed in $10 \%$ of neutral buffered formalin. The tissue was dried using a serial of $n-$ butanol-xylene solution, inserted in paraffin, sectioned at 5$7 \mu \mathrm{m}$ thickness, mounted on glass slides, stained with hematoxylin and eosin as well as Trchrome Heidenhains Azan. Histological examination included percentage of reepithelization, formation of the granulation tissue, number of blood capillaries, and density of collagen in five areas per slide. Percentage of re-epithelization was determined by dividing the length of new epithelium layer by the total length of the wound; the formation of granulation tissue and the number of blood capillaries were examined in the dermis layer under the new epithelium layer. The density of collagen in the granulation tissue was examined by using a scoring method from 0-5 for no collagen until a very dense collagen was found in the wound site (Adriani et al. 2012).

\section{Data analysis}

Results were expressed as mean \pm standard deviation (S.D). The formation of collagen was analyzed descriptively. Statistical significance for the percentage of re-epithelization and the number of blood capillaries was analyzed using one-way ANOVA followed by Duncan multiple range test, whereas the density of collagen was analyzed by Kruskal Wallis test. P values less than 0.05 were considered as significant.

\section{RESULTS AND DISCUSSION}

\section{The effect of treatment on re-epithelization and formation of granulation tissue in wound area}

The histological examination of wound area in day $15^{\text {th }}$ after treatment showed $100 \%$ re-epithelization on all mice (Figure 1). It was characterized by the formation of new epidermis layer above granulation tissue in wound area. This result cannot confirm which one of the treatments has accelerated on the closure of the wound. Histological observation also showed that the diabetic mice (PC) with the most extensive granulation tissue indicated slower healing process than the non-diabetic (NC) and other treatments. In ointment containing EEJFP-treated mice, the granulation tissue area became narrow along with the increase of the concentration (EO1, EO2, EO3). From all of the treatments, the mice given by ointment containing EEJFP at a concentration of $10 \%$ (EO2) had the narrowest granulation tissue when it was compared to the $\mathrm{PC}$ and the reference (REF) groups, and was almost similar to $\mathrm{NC}$ group. It showed that the ointment containing ethanol extract of djengkol fruit peel at concentration of $10 \%$ has a potential to accelerate healing process of diabetic wounds.

\section{The effect of treatment on number of capillaries and density of collagen in wound site}

Proliferative phase in wound healing process was characterized by the formation of epithelium (reepithelization) as well as blood capillaries (neovascularization) and collagen deposition in dermis layer. The phase was undertookon day $5^{\text {th }}$ until $21^{\text {st }}$ of healing process. Histological of wound area that showed the blood capillary and collagen deposition in the dermis after treatment for 14 days and stained with Heidenhain's Azan Trichrome was represented in Figure 2, while the examination results were represented in Table 1. In histological examination, wound area of $\mathrm{NC}$ and $\mathrm{EO} 2$ groups showed higher number of blood capillaries as well as density of collagen that were significantly different from $\mathrm{PC}$, EO1, EO2, and REF groups $(\mathrm{p}<0.05)$. Ointment containing ethanol extract of djengkol fruit peel at a concentration of $10 \%(\mathrm{EO} 2)$ was effective to increase the number of blood capillaries and the density of collagen, and the value was not significantly different from that of non-diabetic mice (NC). These results indicated that the ointment containing ethanol extract of djengkol fruit peel at concentration of $10 \%$ could accelerate wound healing process in diabetic model mice.

Table 2. Effect of treatment groups in a number of blood capillaries of skin wounds

\begin{tabular}{|c|c|c|c|}
\hline $\mathbf{S} / \mathbf{N}$ & Treatments & $\begin{array}{l}\text { Number of blood } \\
\text { capillaries* }\end{array}$ & $\begin{array}{l}\text { Score number of } \\
\text { collagen density** }\end{array}$ \\
\hline $\mathrm{NC}$ & Wounded, non-diabetic mice and treated by petroleum jelly & $19.00 \pm 1.15(\mathrm{~b})$ & $4,00 \pm 0,00(4)$ \\
\hline $\mathrm{PC}$ & Wounded, diabetic mice, and treated by petroleum jelly & $12.50 \pm 1.73(\mathrm{a})$ & $1,75 \pm 0,96(1)$ \\
\hline REF & Wounded, diabetic mice, and treated by Betadine $₫$ ointment & $13.50 \pm 0.58(a)$ & $2,00 \pm 0,82(2)$ \\
\hline EO1 & $\begin{array}{l}\text { Wounded, diabetic mice, and treated by ointment containing EEJFP at } \\
\text { concentration } 5 \%(\mathrm{w} / \mathrm{w})\end{array}$ & $13.75 \pm 1.26(a)$ & $3,75 \pm 0,50(3)$ \\
\hline $\mathrm{EO} 2$ & $\begin{array}{l}\text { Wounded, diabetic mice, and treated by ointment containing EEJFP at } \\
\text { concentration } 10 \%(\mathrm{w} / \mathrm{w})\end{array}$ & $17.75 \pm 0.96(b)$ & $4,00 \pm 0,00(4)$ \\
\hline EO3 & $\begin{array}{l}\text { Wounded, diabetic mice, and treated by ointment containing EEJFP at } \\
\text { concentration } 15 \%(\mathrm{w} / \mathrm{w})\end{array}$ & $12.5 \pm 0.58$ (a) & $3,75 \pm 0,00(3)$ \\
\hline
\end{tabular}

Note: The value is expressed as mean \pm standard deviation $(n=3)$. ${ }^{*}$ Data were analyzed using one-way ANOVA followed by Duncan multiple range test; difference alphabet in the same column showed P values less than 0.05 and considered significant. ** Data were analyzed using Kruskal Wallis test; higher number showed increased rank of collagen density 

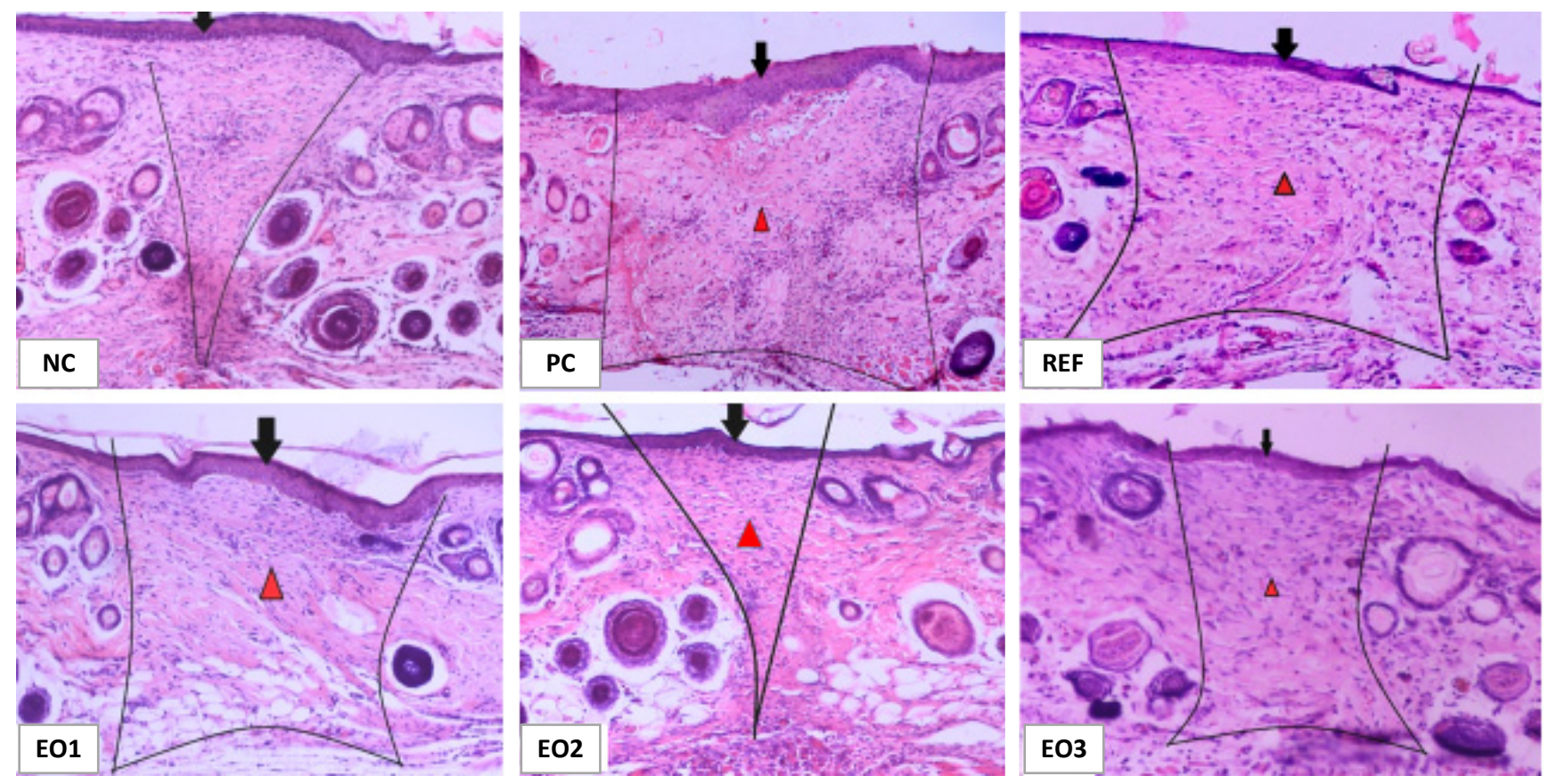

Figure 1. Photomicrograph of the cross section of mice skin from each treatment groups after treatments for 14 days. HematoxylinEosin stain. M.100×. Note: Epidermis in wound site indicated re-epithelization (arrow) and granulation tissue area in dermis (red arrowhead). NC: Negative control, non-diabetic mice; PC: Positive control, diabetic mice; REF: Reference, Betadine ointment-treated diabetic mice; EO: Diabetic mice treated with ointment containing ethanol extract of djengkol fruit peel at concentration $5 \%$ (EO1), 10 $5(\mathrm{EO} 2)$, and $15 \%(\mathrm{EO} 3)$
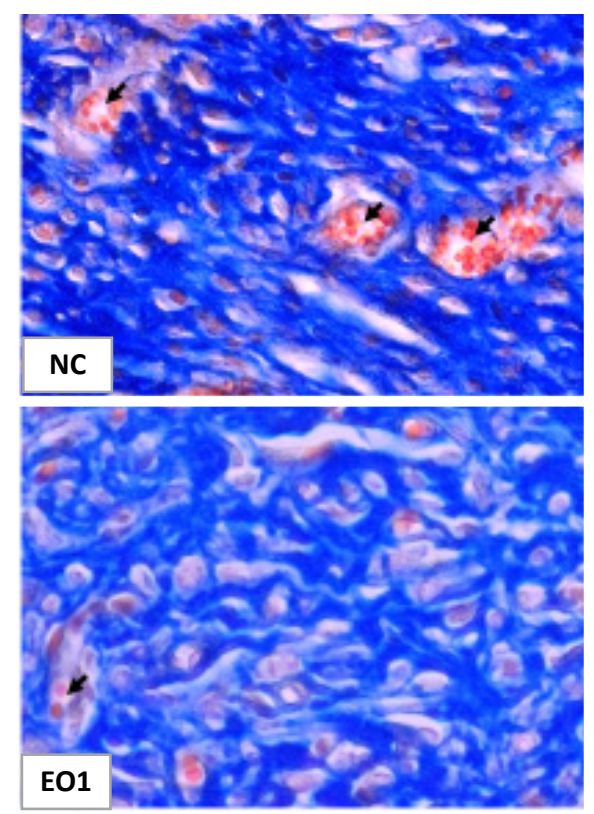
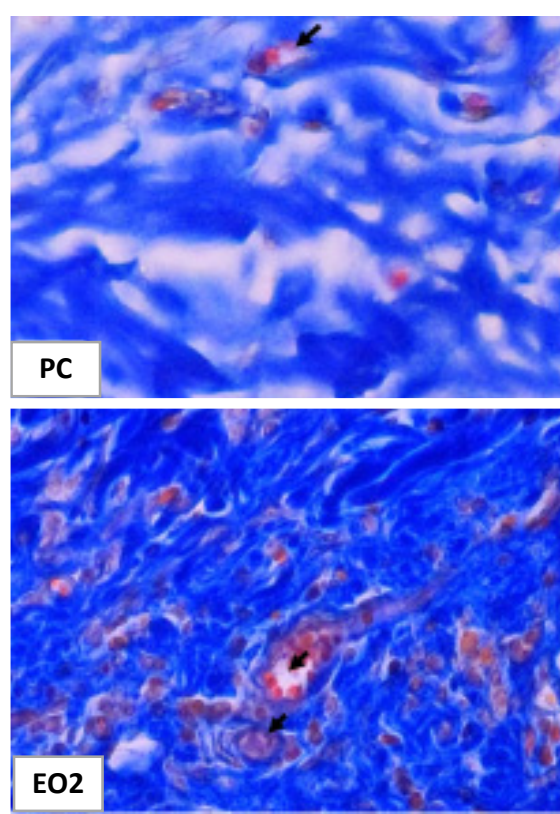
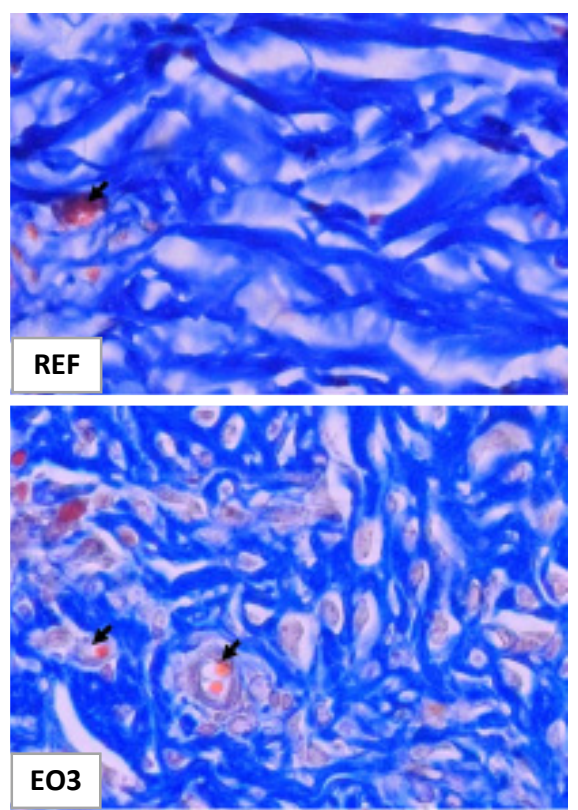

Figure 2 Photomicrograph of the cross section of mice skin from each treatment groups after treatments for 14 days. Heidenhain's Trichrome Azan stain. M.100×. Note: Blood capillary (arrow); collagen in blue color. NC: Negative control, non-diabetic mice; PC: Positive control, diabetic mice; REF: Reference, Betadine ointment-treated diabetic mice; EO: Diabetic mice treated with ointment containing ethanol extract of djengkol fruit peel at concentration $5 \%$ (EO1), 105 (EO2), and $15 \%$ (EO3)

\section{Discussion}

Diabetes mellitus causes impaired wound healing by affecting one or more biological mechanisms of these healing processes. Most often, it is triggered by hyperglycemia, chronic inflammation, angiogenesis and vasculogenesis impairment, micro- and macro-circulatory 
dysfunction, hypoxia, autonomic and sensory neuropathy, and impaired neuropeptide signaling (Baltzis et al. 2014). Diabetes in animal models occured as the results of experimental manipulation, for example by administration of streptozotocin that produces reliable diabetic mice, as shown in this study and others (Wu and Huan 2008; Singh et al. 2014; Furman, 2015; Singh et al. 2017). The induction of streptozotocin leads to the condition of hyperglycemia that affects the wound healing process. Hyperglycemia can lead to glycation of collagen and others protein and to formation of glycation end products, which alter the inflammatory phase. Chronic hyperglycemiainduced inflammation further increases oxidative stress because of the abundance of neutrophils, which can produce a large number of reactive oxygen species and proteases, and macrophages in wound area. In addition, fibroblasts in diabetic wounds have been found to exhibit decreased proliferation, increased apoptosis and decreased migration ability, whereas keratinocytes had an increased proliferation but decreased differentiation and impaired migration ability. Hyperglycemia and chronic inflammation are also considered as the cause of Endothelial Progenitor Cells (EPC) dysfunction and impaired EPC recruitment from the bone marrow, therefore non-enzymatic glycation of vascular basement membranes results in impaired homing of EPCs and hence impaired blood vessel regeneration (Baltzis et al. 2014). Thus, in diabetic mice (PC group), it showed narrower granulation tissue, decreased blood capillaries number and collagen density as shown in this study.

Wound healing occurs as a cellular response to injury and involves activation of keratinocytes, fibroblasts, endothelial cells, macrophages, and platelets. Many growth factors and cytokines released by these cell types are needed to coordinate and maintain healing (Brem and Tomic-Canic 2007). The results of this study showed that the topical treatment with ointment containing ethanol extract of djengkol fruit peel (A. pauciflorum) affects re-epithelization, granulation tissue formation, blood capillaries number and collagen density. Medicinal plant plays a key role in the indigenous system of medicine for diabetes and in the related complications wound healing due to presence of natural compound. Several studies have shown that djengkol fruit peel contains saponin, glycosides, steroids (triterpenoids), alkaloids, flavonoids, tannin, quinones, and polyphenols (Wahyuni et al. 2012; Syafnir et al. 2014; Sihombing et al. 2015).

Phenolic compounds like tannins. phenolic acids, and flavonoids are important plant metabolites that play significant role in the diabetic wound healing. Tannins promotes the wound healing through several cellular mechanisms, chelating the free radicals and reactive species of oxygen, promoting contraction of the wound and increasing the formation of capillary vessels and fibroblasts. Saponin promotes wound healing due to their antioxidant and antimicrobial property which appear to be responsible for wound contraction and elevated rate of reepithelialization. Flavonoids also possess potential of antioxidant and free radical-scavenging effect, enhancing the level of antioxidant enzymes in granuloma tissue (Singh et al. 2014; Singh et al. 2017). Saponin also has properties of precipitating and coagulating red blood cells and also has cholesterol binding properties and supports the formation of foams in aqueous solutions and hemolytic activity (Okwu 2004).

Triterpenoids and flavonoids promote wound healing due to their astringent and antimicrobial property. Flavonoids have also a potent of antioxidant and have free radical-scavenging effect, thus it enhances the level of antioxidant enzymes in granulation tissue (Singh et al. 2014; Singh et al. 2017). Flavonoid compounds can act as vascular-protection agent or as agent to improve blood circulation. The action is by affecting chemical factors in neovascularization and increasing vascular tone, while triterpenoids and alkaloid compounds have the ability to increase collagen synthesis by increasing fibroblast proliferation (Hasanoglu et al. 2001). Flavonoid also has been known to increase collagen synthesis, support the cross-linking of collagen, and decrease the degradation of soluble collagen. This accelerates the conversion of soluble collagen to insoluble collagen, and inhibit the catabolism of soluble collagen. From clinical aspects, collagen deposition in the wound is the most essential phase of healing. Facilitating oxygen diffusion, diminishing oxygen free radical overproduction, and increasing collagen synthesis were found collectively for healing improvement (Lodhi et al. 2016). Collagen is the predominant extracellular protein in the granulation tissue of a healing wound and there is a rapid increase in the synthesis of this protein in the wound area soon after an injury. In addition to providing strength and integrity to a tissue matrix, collagen also plays an important role in homeostasis. Subsequent epithelialization also requires collagen (Chitra et al. 1998; Chen et al. 2005).

From this study, it showed that topical application of the ointment containing EEJFP with concentration of $10 \%$ was effective to accelerate wound healing in diabetic mice models, and it was better than the Betadine ${ }^{\circledR}$ ointmenttreated group as reference. Concentration of $10 \%$ may be the best concentration because according to Douglas and Soejarto (2002), the low concentration of plant extracts will contain only active compounds in small amounts, and then the biological function becomes inferior, but at high concentrations, these could be toxic and give no optimal therapeutic effect.

Betadine ${ }^{\circledR}$ ointment contains $10 \%$ povidone iodine which has bactericidal properties, but in a long term use, this compound can disrupt the synthesis of fibroblasts and keratinocytes (Balin et al. 2002). Fibroblasts are the cells synthesizing collagen, thus, diminishing the healing process. Povidone iodine also has side effects such as irritation, an extension of the inflammatory phase, and cytotoxic on the wound tissue, which could decrease the wound healing process (Sabiston 1995). Wounds treatment of diabetic mice with the ointment containing EEJFP at concentration of $10 \%$ could be more effective than other extract treatments because according to Douglas and Soejarto (2002), the low concentration of plant extracts will contain only active compounds in small amount, and then the biological function becomes inferior, but at high 
concentrations, these could be toxic and give no optimal therapeutic effect. It is concluded that the treatment of diabetic rats with ointment containing ethanol extract of djengkol fruit peel may have beneficial influence on wound healing process because it enhances re-epithelization and granulation tissue, as well as increases capillary number and collagen density.

\section{ACKNOWLEDGEMENTS}

The research was supported by Academic Leadership Grant (ALG), the University of Padjadjaran on behalf of Prof. Johan Iskandar. Therefore, in this opportunity, we gratefully acknowledge the financial support from the Rector of Universitas Padjadjaran through Directorate of Research, Community Service and Innovation (DRPMI) which enables us to conduct the research. The authors would also like to acknowledge the technical assistance of Deden Deni.

\section{REFERENCES}

Adriani WP, Ardianingtyas I, Wulansari NH, Safitri DN, Primalia I, Maharani AS. 2012. Test of binahong leaf (Anredera cardifolia (Tenore) Steenis) utilization on the healing process of wistar rat gingiva (Rattus norvegicus) through observation of collagen fiber density and epithelial thickness. Insisiva Dental Journal 1 (2): 10-16. [Indonesian]

Agyare C, Boakye YD, Bekoe EO, Hensel A, Dapaah SO, Appiah T. 2015. Review: African medicinal plants with wound healing properties, J Ethnopharmacol. DOI: 10.1016/j.jep.2015.11.008.

Balin AK, Pratt L. 2002. Dilute povidone-iodine solutions inhibit human skin fibroblast growth. Dermatol Surg 28: 210-214.

Baltzis D, Eleftheriadou I, Veves A. 2014. Pathogenesis and treatment of impaired wound healing in diabetes mellitus: new insights. Adv Ther 31: $817-836$

Brem H, Tomic-Canic M. 2007. Cellular and molecular basis of wound healing in diabetes. J Clin Invest 117: 1219-1222.

Bunawan H, Dusik L, Bunawan SN, Amin NM. 2013. Botany, Traditional Uses, Phytochemistry and Pharmacology of Archidendron jiringa: A Review. Global J Pharmacol 7 (4): 474-478.

Chen J, Kasper M, Heck T, Nakagawa K, Humpert PM, Bai L, Wu G, Zhang Y, Luther T, Andrassy M, Schiekofer S, Hamann A, Morcos M, Chen B, Stern DM, Nawroth PP, Bierhaus A. 2005. Tissue factor as a link between wounding and tissue repair. Diabetes 54 (7): 21432154.

Chithra P, Sajithlal GB, Chandrakasan G. 1998. Influence of aloe vera on the healing of dermal wounds in diabetic rats. J Ethnopharmacol 59: 195-201.

Furman BL. 2015. Streptozotocin-induced diabetic models in mice and rats. Curr Prot Pharmacol 70:5.47.1-5.47.20. DOI: 10.1002/0471141755.ph0547s70.

Hasanoglu A. Ara C, Ozen S, Kali K, Senol M, Ertas E. 2001. Efficacy of micronized flavonoid fraction in healing of clean and infected wounds. Intl J Angilogy 10 (1): 41-44.

International Diabetes Federation. 2017. Promoting Diabetes Care, Prevention and a Cure Worldwide. https://www.idf.org/

Lodhi S, Jain AP, Rai G, Yadav AK. 2016. Preliminary investigation for wound healing and anti-inflammatory effects of Bambusa vulgaris leaves in rats. $\mathrm{J}$ Ayurveda Integr Med. DOI: 10.1016/j.jaim.2015.07.001.

Mendes JJ, Neves J. 2012. Diabetic foot infections: Current diagnosis and treatment. J Diabet Foot Compl 4 (2): 26-45.

Okwu DE. 2004. Phytochemicals and vitamin content of indigenous spices of Southeastern Nigeria. J Sustain Agric Environ 6 (1): 30-37.

Sabiston DC. 1995. Buku Ajar Bedah Bagian 1. Penerj: Adrianto P, Timan IS. Penerbit Buku Kedokteran EG, Jakarta. [Indonesian]

Sihombing JR, Dharma A, Chaidir Z, Almahdy, Fachrial E, Munaf E. 2015. Phytochemical screening and antioxidant activities of 31 fruit peel extract from Sumatera, Indonesia. J Chem Pharmaceut Res 7 (11): 190-196.

Singh A, Singh PK, Singh RK. 2014. Antidiabetic and wound healing activity of Catharanthus roseus L. in streptozotocin induced diabetic mice. Amer J Phytomed Clin Therapeut 2 (6): 686-692.

Singh A, Srivastav R, Pandey AK. 2017. Protective role of Terminalia chebula in streptozotocin-induced diabetic mice for wound healing activity. Br J Medicine Med Res 22 (2): 1-8.

Suckow MA, Gobbett TA, Peterson RG. 2017. Wound healing delay in the ZDSD Rat. In Vivo 31: 55-60.

Syafnir L, Krishnamurti Y, Ilma M. 2014. Test of antidiabetic activity from ethanol extract of djengkol fruit peel (Archidendron pauciflorum (Benth.) I.C. Nielsen). Prosiding SNaPP2014 Sains, Teknologi, dan Kesehatan.

http://prosiding.lppm.unisba.ac.id/index.php/Sains/article/view/677/p df\#.WW27zekxXIU [Indonesian]

Szkudelski T. 2001. The mechanism of alloxan and streptozotocin action in $\beta$ cells of the rat pancreas. Physiol Res 50: 536-546.

Wahyuni NY, Mayasari N, Abun. 2012. Effect of djengkol fruit peel extract (Pithecellobium jiringa (Jack) Prain) in ration on broiler chicken hematologic values. e-Jurnal Mahasiswa 1 (1). http://jurnal.unpad.ac.id/ejournal/article/view/895/941. [Indonesian]

Winarsih W, Wientarsih I, Sutardi LN. 2012. Turmeric rhizome salmon activity in the wound healing process in diabetic induced mice. Jurnal Veteriner 13 (3): 251-256. [Indonesian]

Wu K, Huan Y. 2008. Streptozotocin-induced diabetic model in mice and rats. Curr Prot Pharmacol 40: 5.47.1-5.47.14.

Yanhendri, Yenny SW. 2012. Topical dosage forms in dermatology. Cermin Dunia Kedokteran 39 (6): 423-430. 